\title{
Feeding Preferences of Marine Harpacticoid Copepods for Various Species of Bacteria
}

\author{
M. Rieper \\ Biologische Anstalt Helgoland, Meeresstation, D-2192 Helgoland, Federal Republic of Germany
}

\begin{abstract}
Selective feeding experiments were carried out in the laboratory with 4 species of marine harpacticoid copepods (Crustacea: Copepoda) and several different strains of bacteria as food. Of the copepod species tested. Tisbe holothuriae and Paramphiascella vararensis were the most discriminating, whereas no clear preferences could be established for Nitocrella polychaeta and Amphiascoides debilis. The bacteria most attractive to the copepods include Moraxella-like species, Vibrio anguillarum (pathogenic for certain fish) and 2 different Flavobacterium spp. A Micrococcus sp. was unattractive and possibly actively avoided by Tisbe, and - to a lesser extent - by Paramphiascella. The preferred strains of bacteria represent different morphological and physiological groups; all are Gramnegative. The Gram-positive bacteria tested (cocci) were not significantly preferred by any of the harpacticoids used in the experiments.
\end{abstract}

\section{INTRODUCTION}

Many factors are known to affect the distribution of harpacticoid copepods. Among these are sand grain size, oxygen content, temperature, and - especially in tidal areas - salinity, light and wave action. The ready availability of food in the form of detrital organic matter or microorganisms such as bacteria, algae and protozoans, is also of great importance.

In the laboratory, some harpacticoid copepods feed on just about everything - from natural food items such as algae, detritus and organic matter on sand grains (Uhlig, 1965; Jansson, 1967; Wulff, 1972; Abraham and Gopalan, 1975; Hardy, 1978; Vanden Berghe and Bergmans, 1981, to mention only a few), to more artificial foods such as tapioca and rice bran (Gopalan, 1977), dried bacteria particles (Rieper, 1978) and vegetables (Kahan, 1979). This might suggest that harpacticoid copepods are indiscriminate feeders or flexible in their nutritional requirements, consuming whatever happens to be available in their immediate surroundings. This may be true in a limited sense for Nitocra typica, which is able to adapt its feeding habits to whatever species of algae occur during different seasons in a salt marsh aufwuchs community (Lee et al., 1976). However, in selective feeding experiments using killed bacteria and algae as food, it could be demonstrated that Tisbe furcata showed a clear prefer- ence for the bacteria, whereas no selectivity for these foods was found in either $T$. holothuriae or $T$. battaglia (Vanden Berghe and Bergmans, 1981).

It has also been shown that some harpacticoid copepods, as well as other meiofauna animals, are able to distinguish between substrates on the basis of the bacteria present, or a microbial 'film' (Meadows, 1964; Gray, 1967, 1968; Gray and Johnson, 1970). Hicks (1977) suggests that a microbial film may influence the choice of an algal substrate by the phytal harpacticoid copepod Porcellidium dilatatum.

The laboratory experiments described in this paper were designed to test several species of harpacticoid copepods for evidence of food selectivity, i. e. to determine their ability to distinguish between different species of bacteria offered as food in otherwise identical substrates (sand piles).

\section{MATERIALS AND METHODS}

\section{Stock Cultures of Copepods}

The harpacticoid copepods used in the experiments were taken from stock laboratory cultures. These include Tisbe holothuriae and Paramphiascella vararensis, both of which occur near the island of Helgo- 
Table 1. Bacteria strains used in selective feeding experiments with harpacticoid copepods

\begin{tabular}{|c|c|c|c|}
\hline Strain no. & Species & Characteristics & Source \\
\hline NCMB 13 & Micrococcus sp. & Gram-positive, non-motile, non-pigmented & \\
\hline NCMB 308 & Moraxella-like group & Gram-negative, non-motile, non-pigmented & National Collection \\
\hline NCMB 407 & Vibrio anguillarum & Gram-negative, motile, non-pigmented & of Marine Bacteria, \\
\hline NCMB 1495 & Planococcus citreus & Gram-positive, motile, yellow pigmented & \\
\hline List 1 & Flavobacterium sp. & Gram-negative, non-motile, orange pigmented & \\
\hline List 2 & Flavobacterium sp. & Gram-negative, non-motile, yellow pigmented & \\
\hline List 3 & Flavobacterium sp. & Gram-negative, non-motile, orange pigmented & Dandy beach sediment \\
\hline List 4 & Vibrio sp. & Gram-negative, motile, non-pigmented & \\
\hline List 7 & Vibrio sp. & Gram-negative, motile, non-pigmented & \\
\hline Helgo 19 & Serratia sp. & Gram-negative, motile, red-violet pigmented & \\
\hline Helgo 20 & Flavobacterium sp. & Gram-negative, non-motile, yellow pigmented & Sublittoral sediments near \\
\hline Helgo 21 & Flavobacterium sp. & Gram-negative, non-motile, brown pigmented & \\
\hline Oil 1 & Mixture & - & 'Amoco Cadiz' chocolate \\
\hline Oil 2 & Mixture & - & $\begin{array}{l}\text { mousse, North Sea surface } \\
\text { water }\end{array}$ \\
\hline
\end{tabular}

land, and Nitocrella polychaeta and Amphiascoides debilis, both originally isolated from a sandy beach area at List/Sylt. The islands of Helgoland and Sylt are located in the southern North Sea off the coast of the Federal Republic of Germany. T. holothuriae cultures received dried mussel meat as food (Uhlig and Noodt, 1966), whereas the other species were fed a fish food mixture. Further details regarding the maintenance of the stock cultures are described in Rieper (1978).

\section{Cultivation and Preparation of Bacteria}

The bacteria used in the experiments include 4 strains obtained from the National Collection of Marine Bacteria (NCMB), Aberdeen, Scotland, UK; 5 strains isolated from a sandy beach at List/Sylt; 3 strains from sublittoral sediments near Helgoland; and 2 mixtures of oil-degrading bacteria from the North Sea, kindly supplied by Dr. W. Gunkel, Helgoland. A list of these bacteria is given in Table 1 . All bacteria cultures were maintained on ZoBell 2216E agar medium (Oppenheimer and ZoBell, 1952; Rheinheimer, 1968). Identification of the strains isolated by the author was made according to the scheme by Shewan et al. (1960) and Bölter (1977).

Dried bacteria particles were prepared as follows: material from an agar culture was inoculated into liquid $2216 \mathrm{E}$ medium without agar and incubated at $20{ }^{\circ} \mathrm{C}$ until a strong turbidity was observed. The material was then centrifuged, washed twice with autoclaved seawater and centrifuged again. The pellet was then dried $4 \mathrm{~h}$ at $70-80^{\circ} \mathrm{C}$ and ground to small particles no larger than $1 \mathrm{~mm}^{3}$. These bacteria particles were stored in a dry place at room temperature $\left(20-22^{\circ} \mathrm{C}\right)$ until use.

\section{Selective Feeding Experiments}

From 25 to 50 healthy harpacticoids were used for each dish in the selective feeding experiments. Adults and late copepodite stages of near-adult size made up 90-95\% of the animals used, whereas the remainder were earlier copepodites. Naupliar stages were not tested in any of the experiments. Animals were used only once and then discarded.

The experiments were performed with Nunc (Nunclon) polyethylene cell-culture Petri dishes; each bottom dish contained low partitions, dividing it into 4 equal quadrants. Into each quadrant $0.1 \mathrm{~g}$ of washed, sterile sand (median grain size 200-315 $\mu \mathrm{m}$ ) was placed and arranged into a small pile. A weighed amount of the bacteria or other food substance to be tested was placed in the center of each pile; in the case of dried bacteria or food particles, $0.1-0.7 \mathrm{mg}$ dry wt was used for each quadrant, or else one loopful of live bacteria from an agar culture. The dishes contained $50 \mathrm{ml}$ autoclaved ' $95 \%$ seawater', i. e seawater consisting of $950 \mathrm{ml}$ aged Helgoland seawater and $50 \mathrm{ml}$ distilled water per liter, with a salinity of about $30 \% \mathrm{~S}$. This amount was sufficient so that the copepods could easily swim over the partitions from one quadrant to the other; the partitions served to keep the sand piles and food particles in one section without mixing due to burrowing action of the copepods.

All experiments were carried out in duplicate, using 2 dishes per experiment; thus the total number of copepods tested in a series with 4 different foods ranged from 100 to 200 individuals. The tests were performed in incubators at $18-20^{\circ} \mathrm{C}$ with a light: dark cycle of $12: 12 \mathrm{~h}$ and ranged from 17 to $24 \mathrm{~h}$ from start to finish. The experiments were timed so that they always covered an uninterrupted dark cycle of $12 \mathrm{~h}$, giving the 
copepods sufficient time to settle and feed. The remaining hours of light before and after each dark cycle were arbitrarily chosen to avoid disturbance caused by other laboratory activities while counting and transferring the copepods. Care was taken to keep the handling of the test animals at a minimum. At the end of an experiment, enough of the seawater in the dishes was rapidly removed with a pipette, so that the level fell below that of the partitions, and the copepods could no longer move to another quadrant. The numbers in the sand piles or water in each quadrant could then be determined without difficulty.

In all experiments duplicate dishes were rotated at $90^{\circ}$ with respect to each other, so that a food substance was never in the same position in the incubator during a given series. Controls were carried out on all copepod species except Nitocrella polychaeta. After over 30 generations have been cultivated continuously in the laboratory, stocks of $N$. polychaeta suddenly weakened and died out before all tests could be completed.

\section{Evaluation}

A statistical evaluation of the experimental results was made whereby the $\mathrm{x}^{2}$-test was carried out on the raw data.

\section{RESULTS}

Results of the selective feeding experiments are represented separately for each species of harpacticoid copepod.

\section{Tisbe holothuriae}

Of the 4 species tested, Tisbe holothuriae showed the most pronounced reaction to the different kinds of food offered (Table 2). In the tests with dried NCMB bacteria strains, NCMB 13 (Micrococcus sp.) was not attractive for Tisbe. NCMB 308 (Moraxella-like group of bacteria) was, on the other hand, an attractive food. In another experimental series, when this species was replaced with the copepods' laboratory food, dried Mytilus edulis meat, the bacteria strain NCMB 407 (Vibrio anguillarum, pathogenic to fish) proved to be the next choice. In both sets of experiments there was significant $(p<0.001)$ deviation from random distribution in the Petri dishes containing the sand piles with the different food particles.

In tests in which both living and dried North Sea sediment bacteria were used, Tisbe holothuriae showed a clear preference for the yellow pigmented Helgo 21 strain. The order of preference was the same for both the living and dried bacteria offered, indicat-
Table 2. Tisbe holothuriae. Results of selective feeding experiments offering various species of bacteria

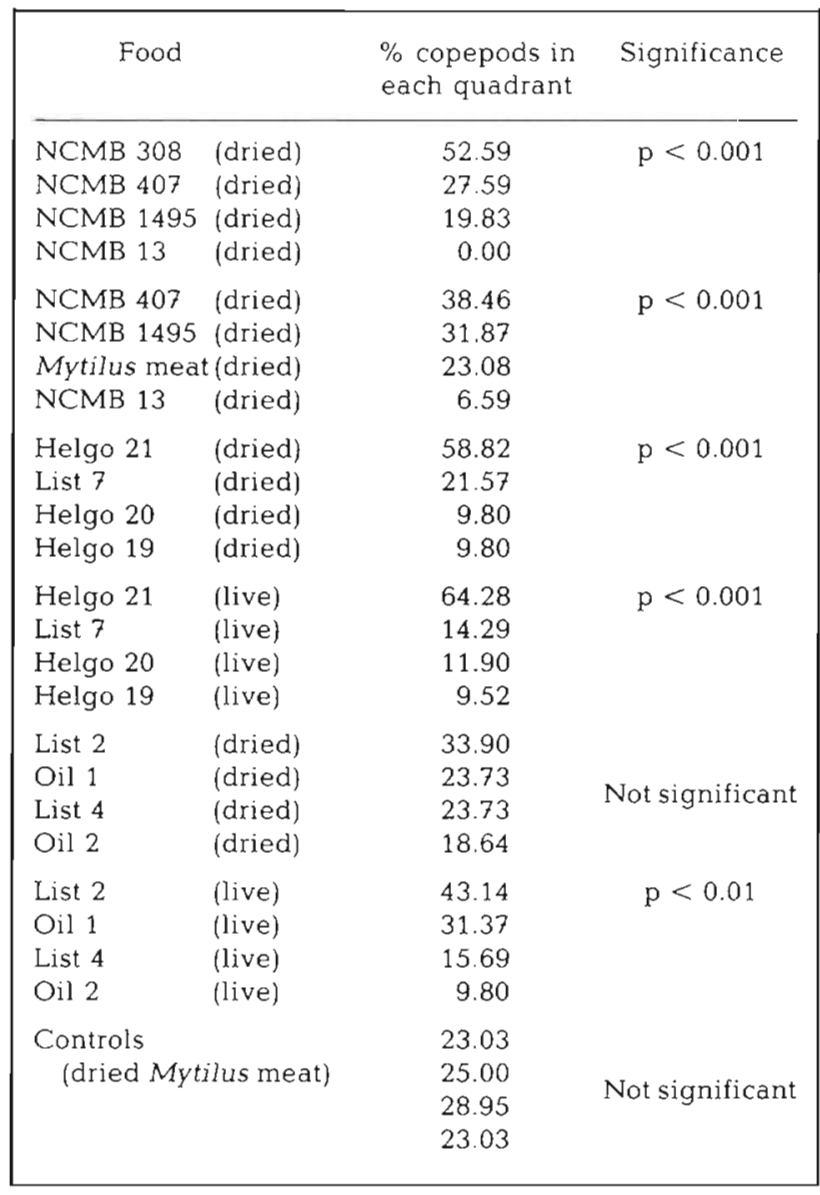

ing that the drying process did not greatly alter the attractive property of these bacteria. The same holds true for experiments in which 2 sediment bacteria species and 2 different mixtures of oil-degrading bacteria were used. List 2, a yellow pigmented Flavobacterium sp., was preferred by $T$. holothuriae over the other bacteria offered, but the statistical evaluation of the results shows little $(p<0.01)$ or no significant deviation from random distribution of the copepods in the dishes. The controls showed that there was not a significant tendency for these copepods to prefer any particular quadrant over the other.

\section{Paramphiascella vararensis}

In contrast to Tisbe, Paramphiascella vararensis did not demonstrate any pronounced preference for the NCMB bacteria species (Table 3). However, when NCMB 308 was replaced with the laboratory food of stock cultures, there was a significant deviation $(p<0.001)$ from random distribution. Results of test 
Table 3. Paramphiascella vararensis. Results of selective feeding experiments offering various species of bacterı

\begin{tabular}{|lccc|}
\hline \multicolumn{1}{|c}{ Food } & & $\begin{array}{c}\text { \% copepods in } \\
\text { each quadrant }\end{array}$ & Significance \\
& & 28.13 & \\
NCMB 407 & (dried) & 26.56 & Not significant \\
NCMB 308 & (dried) & 25.00 & \\
NCMB 1495 & (dried) & 20.31 & \\
NCMB 13 & (dried) & 42.86 & p $<0.001$ \\
Fish food mix. & (dried) & 25.27 & \\
NCMB 1495 & (dried) & 17.58 & \\
NCMB 407 & (dried) & 14.29 & \\
NCMB 13 & (dried) & 33.33 & p $<0.05$ \\
List 7 & (dried) & 31.25 & \\
Helgo 21 & (dried) & 23.96 & \\
Helgo 19 & (dried) & 11.46 & \\
Helgo 20 & (dried) & 39.84 & p $<0.001$ \\
List 2 & (dried) & 39.83 & \\
List 1 & (dried) & 26.83 & \\
List 3 & (dried) & 26.83 & \\
List 4 & (dried) & 6.50 & \\
Controls & & 27.64 & \\
(fish food mix, dried) & 18.70 & Not significant \\
& & 23.58 & \\
& & 30.08 & \\
& & & \\
\hline
\end{tabular}

series with dried North Sea sediment bacteria showed that List 2 (Flavobacterium sp.) and List 7 (Vibrio sp.) were among the most attractive bacteria offered; in these experiments, a significant deviation was demonstrated $(\mathrm{p}<0.05 ; \mathrm{p}<0.001)$. Controls were not significant.

\section{Nitocrella polychaeta}

This species could not be tested as extensively as those mentioned above. Tests were carried out solely with bacteria isolated from the littoral sediments in which Nitocrella polychaeta was found (Table 4). Both dried and living bacteria were used in the experiments. Although the order of preference for the bac-

Table 4. Nitocrella polychaeta. Results of selective feeding experiments offering various species of bacteria

\begin{tabular}{|ccc|}
\hline Food & $\begin{array}{c}\text { \% copepods in } \\
\text { each quadrant }\end{array}$ & Significance \\
\hline List 4 (dried) & 28.65 & \\
List 1 (dried) & 27.60 & Not significant \\
List 2 (dried) & 25.00 & \\
List 3 (dried) & 18.75 & \\
List 4 (live) & 31.03 & \\
List 1 (live) & 30.34 & \\
List 2 (live) & 21.38 & \\
List 3 (live) & 17.24 & \\
\hline
\end{tabular}

teria offered was the same in both cases, a statistical evaluation of the results showed either no significance or only at the $\mathrm{p}<0.05$ level. Controls were not made.

\section{Amphiascoides debilis}

Results of tests performed with the four NCMB strains and the sediment bacteria Lists 1-4 showed a strong tendency of Amphiascoides debilis to prefer the same quadrant - that nearest to the incubator door regardless of the food offered. A series of control experiments using both fish food mixture and Mytilus meat confirmed the suspicion that, in contrast to the other copepod species tested, A. debilis was significantly influenced in its choice of quadrants by a factor other than the food itself. It is possible that $A$. debilis is sensitive to a slight gradient in the incubators, such as temperature or light, which does not affect the other copepods tested.

\section{DISCUSSION}

The selective feeding experiments show that the following strains of bacteria were significantly preferred: by Tisbe, Moraxella-like sp. (NCMB 308), Vibrio anguillarum (NCMB 407) and Flavobacterium sp. (Helgo 21); by Paramphiascella, in addition to the fish food mixture, Flavobacterium sp. (List 2); by Nitocrella, though not highly significant, Vibrio sp. (List 4). For the most part, these bacteria belong to different morphological and physiological groups. Motile and non-motile forms, pigmented and non-pigmented, are represented. All are Gram-negative. The 2 Gram-positive strains, both cocci, were not significantly preferred by any of the copepods tested in the feeding experiments.

The use of live instead of dried bacteria in some of the experiments did not alter the order of preference, indicating that the drying procedure did not greatly influence the attractiveness of the bacteria used, although in some cases the significance of the results differed. Tests performed on Vibrio sp. (List 4) bacteria particles after drying showed that this normally actively growing strain was no longer viable and formed no colonies on $2216 \mathrm{E}$ agar medium. Since the dried bacteria would not have produced a film during the experiments, the preferences exhibited by the copepods were probably due to the bacterial substance itself. There may possibly be a chemical attraction or 'taste' involved. That feeding actually took place during the experiments could be demonstrated by the feces present in the dishes. Where strongly pigmented bacteria were used, material in the digestive tracts of 
the copepods, as well as the feces, showed the same pigmentation

Among the species of harpacticoids tested, Tisbe holothuriae and Paramphiascella vararensis were the most discriminating. Both species are very active in their movements. Particularly in $T$. holothuriae, all developmental stages from early nauplii to adults are excellent swimmers and thus able to move rapidly from one substrate to another in search of food. It is possible that some less active species may not be as discriminating in their feeding habits, being content with whatever food is immediately available in their environment.

On the basis of the results presented here alone, it would be premature to draw conclusions about the feeding behavior of harpacticoid copepods in general. It is not known, for example, how often the copepods moved about from one sand pile to another, or whether the 'preferred' bacteria were not simply the least obnoxious ones in a given series tested. Extensive studies on the individual copepod species with bacteria isolated from their environment should provide answers to these questions. If selective feeding actually does take place in nature, however, there are some interesting implications. The availability of food is an important factor in the distribution of organisms in a given environment. Competition for nutrients would be reduced if the species present had different food requirements or preferences - for example, if certain harpacticoid copepods in a biotope specialized on different groups of bacteria colonizing sand grains, detritus particles, macroalgae or other substrates. It has been shown in the laboratory that identical species of bacteria do not have the same relative food value for different harpacticoid copepods in terms of the generation times of these animals (Rieper, 1978). Since microorganisms undoubtedly form part of the diet of harpacticoids in nature, the selective feeding on certain groups of bacteria would result in a decrease in numbers of these bacteria, bringing about an alteration in the microbial population. This would be of great interest particularly if the bacteria which were preferentially eaten included oil degraders, pathogenic species or others whose properties give them a special role in the ecosystem.

\section{LITERATURE CITED}

Abraham, S., Gopalan, U. K. (1975). Growth of an estuarine harpacticoid copepod Nitocra spinipes Boeck cultured in the laboratory. Bull. Dep. mar. Sci. Univ. Cochin 7: 309-318
Bölter, M. (1977). Numerical taxonomy and character analysis of saprophytic bacteria isolated from the Kiel Fjord and the Kiel Bight. In: Rheinheimer, G. (ed.) Microbial ecology of a brackish water environment. Springer-Verlag, Berlin, pp. $148-178$

Gopalan, U. K. (1977). Experimental mass culture of a harpacticoid copepod Nitocra spinipes Boeck. In: Proc. Symp. Warm Water Zoopl. Spec. Publ. UNESCO/NIO, pp. $558-562$

Gray, J. S. (1967). Substrate selection by the archiannelid Protodrilus rubropharyngeus. Helgoländer wiss. Meeresunters. 15: 253-268

Gray, J. S. (1968). An experimental approach to the ecology of the harpacticoid Leptastacus constrictus Lang. J. exp. mar. Biol. Ecol. 2: 278--292

Gray, J. S., Johnson, R. M. (1970). The bacteria of a sandy beach as an ecological factor affecting the interstitial gastrotrich Turbanella hyalina Schultze. J. exp. mar. Biol. Ecol. 4: 119-133

Hardy, B. L. S. (1978). A method for rearing sand-dwelling harpacticoid copepods in experimental conditions. J. exp. mar. Biol. Ecol. 34: 143-149

Hicks, G. R. F. (1977). Observations on substrate preference of marine phytal harpacticoids (Copepoda). Hydrobiologia 56: $7-9$

Jansson, B.-O. (1967). The importance of tolerance and preference experiments for the interpretation of mesopsammon field distributions. Helgoländer wiss. Meeresunters. 15: $41-58$

Kahan, D. (1979). Vegetables as food for marine harpacticoid copepods. Aquaculture 16: 345-350

Lee, J. J., Tietjen, J. H., Garrison, J. R. (1976). Seasonal switching in the nutritional requirements of Nitocra typica, a harpacticoid copepod from salt marsh aufwuchs communities. Trans. Am. Microsc. Soc. 95: 628-637

Meadows, P. S. (1964). Experiments on substrate selection by Corophium species: films and bacteria on sand particles. J. exp. Biol. 41: 499-511

Oppenheimer, C. H., ZoBell, C. E. (1952). The growth and viability of sixty-three species of marine bacteria as influenced by hydrostatic pressure. J. mar. Res. 11: 10-18

Rheinheimer, G. (1968). Beobachtungen über den Einfluß von Salzgehaltsschwankungen auf der Bakterienflora der westlichen Ostsee. Sarsia 34: 253-262

Rieper, M. (1978). Bacteria as food for marine harpacticoid copepods. Mar. Biol. 45: 337-345

Shewan, J. M., Hobbs, G., Hodgkiss, W. (1960). A determinative scheme for the identification of certain genera of Gram-negative bacteria, with special reference to the Pseudomonadaceae. J. appl. Bact. 23: 379-390

Uhlig, G. (1965). Die mehrgliedrige Kultur litoraler Folliculiniden. Helgoländer wiss. Meeresunters, 12: 52-60

Uhlig, G., Noodt, W. (1966). Tisbe helgolandica n. sp. aus dem Seewasser-Freibad Helgoland (Crustacea, Copepoda). Kieler Meeresforsch. 22: 133-137

Vanden Berghe, W., Bergmans, M. (1981). Differential food preferences in three co-occurring species of Tisbe (Copepoda, Harpacticoida). Mar. Ecol. Prog. Ser. 4: 213-219

Wulff, F. (1972). Experimental studies on physiological and behavioural response mechanisms of Nitocra spinipes (Crustacea: Harpacticoida) from brackish water rockpools Mar. Biol. 13: 325-329 